\title{
Bibliography
}

Adams, J. (1971), 'The second ethical problem in $R v$ Turner: the limits of an advocate's discretion', Criminal Law Review, 252.

Alge, D. (2013), 'The effectiveness of incentives to reduce the risk of moral hazard in the defence barrister's role in plea bargaining', Legal Ethics, 16(1): 162.

Alschuler, A. (1975), 'The defense attorney's role in plea bargaining', Yale Law Journal, 84: 1179.

Alschuler, A. (1981), 'The changing plea bargaining debate', California Law Review, 69: 652.

Alschuler, A. (1983), 'Implementing the criminal defendant's right to trial: alternatives to the plea bargaining system', University of Chicago Law Review, 50: 931.

Anderson, D. (2011), Report on the Operation in 2010 of the Terrorism Act 2000 and of Part 1 of the Terrorism Act 2006, London: Stationery Office.

Ashworth, A. (2010), 'Coroners and Justice Act 2009: sentencing guidelines and the Sentencing Council', Criminal Law Review, 388.

Ashworth, A. (2012), 'Departures from the sentencing guidelines', Criminal Law Review, 2: 81.

Ashworth, A. and M. Redmayne (2010), The Criminal Process, 4th edn, Oxford: Oxford University Press.

Atkinson, J.M. and P. Drew (1979), Order in Court, London: Macmillan.

Auld, Sir Robin (2001), Review of the Criminal Courts of England and Wales, London: Lord Chancellor's Department.

Baksi, C. (2012a), 'LSC improvements fail to satisfy auditor', Law Society Gazette, 11 July.

Baksi, C. (2012b), 'Spending watchdog trains fire on interpreter contracting chaos', Law Society Gazette, 12 November.

Baksi, C. (2013a), 'Chris Grayling', Law Society Gazette, 20 May.

Baksi, C. (2013b), 'CPS under fire for failures in two serious cases', Law Society Gazette, 24 June.

Baksi, C. (2013c), "Overwhelming" support for action as 400 barristers stay away from court', Law Society Gazette, 22 April.

Baksi, C. (2014), 'CPS warns barristers against taking part in legal aid protest', Law Society Gazette, 3 March. 
Balbus, I. (1973, 1977), The Dialectics of Legal Repression, New York: Russell Sage.

Baldwin, J. (1985), Pre-Trial Justice, Oxford: Basil Blackwell.

Baldwin, J. (1997), 'Understanding judge ordered and directed acquittals in the Crown Court', Criminal Law Review, 536.

Baldwin, J. and F. Feeney (1986), 'Defence disclosure in the magistrates' courts', Modern Law Review, 44: 593.

Baldwin, J. and M. McConville (1977), Negotiated Justice, London: Martin Robertson.

Baldwin, J. and M. McConville (1978a), 'Legal carve-up and legal cover-up', British Journal of Law and Society, 5(2): 228.

Baldwin, J. and M. McConville (1978b), 'Allegations against lawyers: some evidence from criminal cases in London', Criminal Law Review, 741.

Ball, R. and J. Drury (2012), 'Representing the riots: the (mis)use of statistics to sustain ideological explanation', Riotstats, 106.

Bankowski, Z. and G. Mungham (1976), Images of Law, London: Routledge.

Barclay, G. and C. Tavares (1999), Information on the Criminal Justice System in England and Wales: Digest 4, London: Home Office.

Bar Council of England and Wales (2013), 'Response to the Ministry of Justice Transforming Legal Aid Consultation', 4 June, available at: http://www.barcouncil.org.uk/media/213867/the_bar_council_response _to_moj_transforming_legal_aid_consultation.pdf

Barry, J. (2010), 'A barrister's role in the plea decision', PhD thesis, University of London, available at: http://qmro.qmul.ac.uk/jspui/ handle/123456789/394

BBC News (2014), 'Police to be told not to confer before writing up notes,' 5 March.

Bedford, S. (1958), The Best We Can Do, Harmondsworth: Penguin.

Bennet, J. and K. Miller (1990), Delay in Summary Criminal Proceedings: A Study of Six Sheriff Courts, Scottish Office: Central Research Unit.

Bennett, R. (1993), 'Criminal justice', London Review of Books, 24 June, 15(12): 5.

Bentham, J. (1781), An Introduction to the Principles of Morals and Legislation, Oxford: Clarendon Press.

Bentham, J. (1840), The Rationale of Judicial Evidence in 'The Works of Jeremy Bentham now first collected; under the superintendence of his executor, John Bowring', Google Books.

Berger, M. (1976), 'The case against plea bargaining', American Bar Association Journal, 62: 621.

Bingham, Lord (2006), 'The rule of law', 6th David Williams Lecture, Centre for Public Law, University of Cambridge, 16 November, avail- 
able at: http://www.cpl.law.cam.ac.uk/Media/THE\%20RULE $\% 20$ OF\% 20LAW\%202006.pdf

Birkett, Lord (1961), Six Great Advocates, Harmondsworth: Penguin Books.

Blackstock J., E. Cape, J. Hodgson, A. Ogorodova and T. Spronken (2013), Inside Police Custody: An Empirical Account of Suspects' Rights in Four Jurisdictions, Cambridge: Intersentia Ltd.

Blackstone, W. (1765), Commentaries on the Laws of England, Vol. 1.

Blake, M. and A. Ashworth (1998), 'Some ethical issues in prosecuting and defending criminal cases', Criminal Law Review, 16.

Block, B., C. Corbett and J. Peay (1993a), Ordered and Directed Acquittals in the Crown Court, Royal Commission on Criminal Justice, Research Study No. 15, London: HMSO.

Block, B., C. Corbett and J. Peay (1993b), 'Ordered and directed acquittals in the Crown Court: A time of change?', Criminal Law Review, 95.

Blowe, K. (2011), 'Policing the police', Red Pepper, 9 March.

Blumberg, A. (1967), Criminal Justice, Chicago IL: Quadrangle.

Blume, J. (2007), The Dilemma of the Criminal Defendant with a Prior Record - Lessons from the Wrongfully Convicted, Cornell: Cornell Law School Legal Studies Research Paper Series No. 83.

Bonomy, Lord (2002), Improving Practice: The 2002 Review of the Practices and Procedure of the High Court of Justiciary, available at: http://www. scotland.gov.uk/Publications/2002/12/15847/14122

Borrie, G. and J. Varcoe (1970), Legal Aid in Criminal Proceedings: $A$ Regional Survey, Birmingham: Institute of Judicial Administration.

Bottoms, A. and J. McClean (1976), Defendants in the Criminal Process, London: Routledge.

Boulton, W.W. (1953, 1957, 1961, 1965, 1971, 1975), A Guide to Conduct and Etiquette at the Bar of England and Wales, London: Butterworths.

Bourke, S. (1970), The Springing of George Blake, London: Cassell.

Bowers, J. (2008), 'Punishing the innocent', University of Pennsylvania Law Review, 156: 1117.

Bowles, R. and A. Perry (2009), International Comparison of Publiclyfunded Legal Services and Justice Systems, London: Ministry of Justice, Research Series 14/09, October.

Bowling, B. and C. Phillips (2002), Racism, Crime and Justice, Harlow: Longman.

Boyle, K., T. Hadden and P. Hillyard (1975), Law and State: The Case of Northern Ireland, London: Martin Robertson.

Brabin, Justice (1966), The Case of Timothy John Evans: Report of an Inquiry, Cmnd. 3101, London: HMSO. 
Bridges, L. (1975), 'The Dialectics of Legal Repression', Race and Class, 17: 83 .

Bridges, L. (1994), 'Normalizing injustice: The Royal Commission on Criminal Justice', Journal of Law \& Society, 21: 20.

Bridges, L. (2006), 'The ethics of representation on guilty pleas', Legal Ethics, 9(1): 80.

Bridges, L. (2012), 'Four days in August: the UK riots', Race \& Class, 54(1): 1.

Bridges, L. and T. Bunyan (1983), 'Britain's new urban policing strategy - The Police and Criminal Evidence Bill in context', Journal of Law \& Society, 10(1): 85.

Bridges, L. and E. Cape (2008), CDS Direct: Flying in the Face of the Evidence, London: Centre for Crime and Justice Studies.

Bridges, L. and S. Choongh (1998), Improving Police Station Advice: The Impact of the Accreditation Scheme for Police Station Legal Advisers, London: Law Society's Research and Policy Planning Unit/Legal Aid Board.

Bridges, L. and M. McConville (1997), 'Keeping faith with their own convictions: The Royal Commission on Criminal Justice', in M. McConville and L. Bridges (eds), Criminal Justice in Crisis, Cheltenham, UK and Lyme, NH, USA: Edward Elgar.

Bridges, L., E. Cape, P. Fenn, A. Mitchell, R. Moorhead and A. Sherr (2007), Evaluation of the Public Defender Service in England and Wales, London: HMSO.

Bridges, L., S. Choongh and M. McConville (2000), Ethnic Minority Defendants and the Right to Elect Jury Trial, London: Commission for Racial Equality.

Bridges, L., J. Hodgson, M. McConville and A. Pavlovic (1997), 'Can critical research influence policy?' British Journal of Criminology, 37: 378.

Brogden, A. (1981), 'Sus is dead: What about "SAS"?', New Community, 9: 44.

Brogden, M. (1982), Police, Autonomy and Consent, London: Academic Press.

Brogden, M. (1991), On the Mersey Beat, Oxford: Oxford University Press.

Brown, G. (2013), 'Sentence discounting in England and Scotland - some observations on the use of comparative authority in sentence appeals', Criminal Law Review, 8: 673.

Bryan, I. (1997), Interrogation and Confession: A Study of Progress, Process and Practice, Dartmouth: Ashgate.

Bull, R. (2011), 'The investigative interviewing of children and other vulnerable witnesses: psychological research and working/professional practice', Legal and Criminological Psychology, 15(1): 5. 
Burney, E. (1979), Magistrate, Court and Community, London: Hutchinson. Burton, F. and P. Carlen (1979), Official Discourse: On Discourse Analysis, Government Publications, Ideology and the State, London: Routledge and Kegan Paul.

Butler, T. and M. Garsia (1969), Archbold, Pleading, Evidence \& Practice in Criminal Cases, 37th edn, London: Sweet \& Maxwell.

Butler, T. and S. Mitchell (1973), Archbold, Pleading, Evidence \& Practice in Criminal Cases, 38th edn, London: Sweet \& Maxwell.

Cain, M. (1979), 'The general practice lawyer and the client: towards a radical conception', International Journal of the Sociology of Law, 7: 331.

Callander, I. (2013), 'The pursuit of efficiency in the reform of the Scottish fiscal fine: should we opt out of the conditional offer?', Scots Law Times, 5: 37-43; 6: 47-53.

Cape, E. (2004), 'The rise (and fall?) of a criminal defence profession', Criminal Law Review, 72.

Cape, E. (2013), 'The counter-terrorism provisions of the Protection of Freedoms Act 2012: preventing misuse or a case of smoke and mirrors?', Criminal Law Review, 5: 385.

Carlen, P. (1976), Magistrates' Justice, London: Martin Robertson.

Carlile, Lord (2010), Report on the Operation in 2009 of the Terrorism Act 2000 and of Part 1 of the Terrorism Act 2006, July. London: TSO.

Carter, Lord (2006), Legal Aid: A Market-Based Approach to Reform, London, available at: http://www.lccsa.org.uk/assets/documents/consul tation/carter\%20review\%2013072006.pdf

Casale, S. (2013), Report of the Independent External Review of the IPCC Investigation into the Death of Sean Rigg (May), available at: http:// www.ipcc.gov.uk/sites/default/files/Documents/investigation_commis sioner_reports/Review_Report_Sean_Rigg.PDF

Chibnall, S. (1977), Law and Order News: An Analysis of Crime Reporting in the British Press, London: Tavistock Publishing.

Choongh, S. (1997), Policing as Social Discipline, Oxford: Clarendon Press.

Christian, L. (1985), 'Restriction without conviction: the role of the courts in legitimising police control in Nottinghamshire', in B. Fine and R. Millar (eds), Policing the Miners' Strike, London: Lawrence \& Wishart.

Clarkson, C., A. Cretney, G. Davis and J. Shepherd (1994), 'Assaults: the relationship between seriousness, criminalisation and punishment', Criminal Law Review, 4.

Clough, J. and A. Jackson (2012), 'The game is up: proposals on incorporating effective disclosure requirements into criminal investigations', Criminal Lawyer, 211: 3. 
Cluss, P.A., J. Boughton, E. Frank, B.D. Stewart and D. West (1983), 'The rape victim: psychological correlates of participation in the legal process', Criminal Justice and Behavior, 10: 342.

Cockburn, A.W. (1952), 'In lumine: an address on advocacy', Faculty of Law, Southampton.

Cohen, S. (1979), 'The punitive city: notes on the dispersal of social control', Contemporary Crises, 3: 339.

Cookson, G. (2011), Unintended Consequences: The Cost of the Government's Legal Aid Reforms, London: King's College London.

Council of Circuit Judges (2013), Response to the Ministry of Justice Transforming Legal Aid Consultation, June 2013, available at: http:// www.judiciary.gov.uk/Resources/JCO/Documents/Consultations/cocjresponse-transforming-legal-aid-june-2013.pdf

Cox, B., J. Shirley and M. Short (1977), The Fall of Scotland Yard, London: Penguin Books Ltd.

Cretney, A. and G. Davis (1995), Punishing Violence, London: Routledge.

Cretney, A. and G. Davis (1997), 'Prosecuting domestic assault: victims failing courts or courts failing victims?', Howard Journal, 32(2): 146.

Criminal Law Revision Committee (1972), Eleventh Report, Evidence (General), Cmnd 4991, London: HMSO.

Crown Office Notice (1980), Journal of the Law Society of Scotland, 25(4): April.

Crown Prosecution Service (CPS) (2009), Annual Report and Resource Accounts for the Period April2008-March 2009, London: Stationery Office, available at: http://www.cps.gov.uk/publications/reports/2008/index.html

Crown Prosecution Service (CPS) (2013), Response to the Ministry of Justice Transforming Legal Aid Consultation, 4 June, available at: http:// www.cps.gov.uk/consultations/cps_response_to_legal_aid_consultation. pdf

Curran, P. (1991), 'Discussions in the judge's private room', Criminal Law Review, 79.

David, Judge (1978), 'In the Crown Court', The Magistrate, 34: 74.

Dawes, W., P. Harvey, B. Mackintosh, F. Nunney and A. Phillips (2011), Attitudes to Guilty Plea Reductions, Sentencing Council Research Series 02/11, London: Sentencing Council.

De Burgh, H. (2000), Investigative Journalism: Context and Practice, London: Routledge.

Dell, S. (1971), Silent in Court, London: Bell.

Dempsey, M. (2009), Prosecuting Domestic Violence, Oxford: Oxford University Press.

Demuth, C. (1978), Sus: A Report of the Vagrancy Act of 1824, London: Runnymede Trust. 
Denning, Lord (1963), The Circumstances Leading to the Resignation of the Former Secretary for War, Mr. J. D. Profumo, Cmnd. 2152, London: HMSO.

Denyer, R. (2008), Case Management in the Crown Court, Oxford: Hart Publishing.

Denyer, R. (2012), Case Management in Criminal Trials, 2nd edn, Oxford: Hart Publishing.

Department for Communities and Local Government (2013), Response to the Riots: Communities and Victims Panel's Final Report, 12 July.

Department for Constitutional Affairs (2006a), Judicial Statistics: England and Wales for the Year 2005, CM 6799, May.

Department for Constitutional Affairs (2006b), Delivering Simple, Speedy, Summary Justice, 13 July.

Dervan, L. (2012), 'Bargained justice: plea bargaining's innocence problem and the Brady safety-valve', Utah Law Review, 51.

Dervan, L. and V. Edkins (2012), 'The innocent defendant's dilemma: an innovative empirical study of plea bargaining's innocence problem', available at: http://ssrn.com/abstract $=2071397$

Devlin, J.D. (1960), Criminal Courts and Procedure, London: Butterworth.

Devlin, Lord (1979), The Judge, Oxford: Oxford University Press.

Devlin, Lord (1991), 'The conscience of the jury', Law Quarterly Review, 107: 398.

Devlin, P. (1956), Trial by Jury, London: Stevens.

Devlin, P. (1960), The Prosecution Process in England, Oxford: Oxford University Press.

Dicey, A.V. (1885), Introduction to the Study of the Law of the Constitution, 1st edn, Macmillan.

Dignan, J. and A. Whynne (1997), 'A microcosm of the local community? Reflections on the composition of the magistracy in a Petty Sessional Division in the North Midlands', British Journal of Criminology, 37: 184.

Dixen, B. (2012), 'The record of the House of Lords in Strasbourg', Law Quarterly Review, 128 (July), 354.

Dixon, D., A.K. Bottomley, C.A. Coleman, M. Gill and D. Wall (1989), 'Reality and rules in the construction and regulation of police suspicion', International Journal of the Sociology of Law, 17: 185.

Doob, A. and C. Webster (2003), 'Sentence severity and crime: accepting the null hypothesis', in M. Tonry (ed.), Crime and Justice: A Review of Research, Vol. 30, Chicago: University of Chicago Press.

Doughty Street Chambers (2013), 'Response to the Ministry of Justice Transforming Legal Aid Consultation', 4 June, available at: http:// www.doughtystreet.co.uk/documents/uploaded-documents/Transform ing_Legal_Aid_-_Doughty_Street_Chambers_Response_(2).pdf 
Downes, D. and R. Morgan (2002), 'The skeletons in the cupboard: the politics of law and order at the turn of the millennium', in M. Maguire, R. Morgan and R. Reiner (eds), The Oxford Handbook of Criminology, Oxford: Oxford University Press.

Du Cann, R. (1964), The Art of the Advocate, London: Penguin Group.

Duff, P. (1996a), 'The not proven verdict: jury mythology and "moral panics", Juridicial Review, 1: 1.

Duff, P. (1999b), 'The Scottish criminal jury: a very peculiar institution', Law and Contemporary Problems, 62: 73.

Duff, P. (1999c), 'The Prosecution Service: independence and accountability', in P. Duff and N. Hutton (eds), Criminal Justice in Scotland, Aldershot: Ashgate.

Dworkin, R. (1985), 'Principle, policy, procedure', in R. Dworkin, $A$ Matter of Principle, Cambridge, MA: Harvard University Press.

East, R. and P. Thomas (1985), 'Freedom of movement: Moss v McLachlan', Journal of Law \& Society, 12(1): 77.

Eastwood, N., M. Shiner and D. Bear (2013), The Numbers in Black and White: Ethnic Disparities in the Policing and Prosecution of Drug Offences in England and Wales, Release (LSE consulting), August.

Edwards, A. (2010), 'Do the defence matter?', International Journal of Evidence and Proof, 14: 119.

Eisenstein, J. and H. Jacob (1977), Felony Justice, Boston: Little, Brown.

Ellis, R. and S. Biggs (2013), 'Simple cautions', Archbold Review, 5: 6.

Ellison QC, M. (2014), 'The Stephen Lawrence Independent Review Possible Corruption and the role of undercover policing in the Stephen Lawrence case (summary of findings)', (Ellison Report), UK: HMSO, HC1094, 6 March.

Equalities and Human Rights Commission (EHRC) (2010), Stop and Think: A Critical Review of the Use of Stop and Search Powers in England and Wales, London: EHRC.

Equalities and Human Rights Commission (EHRC) (2012), Race Disproportionality in Stops and Searches under Section 60 of the Criminal Justice and Public Order Act, 1994, available at: http://www.equality humanrights.com/uploaded_files/research/bp_5_final.pdf

Faulkner, D. (2010), Criminal Justice and Government at a Time of Austerity: An Extended Review, London: Criminal Justice Alliance.

Feeley, M. (1976), 'The concept of laws in social science: a critique and notes on an expanded view', Law and Society Review, 10: 497.

Feeley, M. (1977, 1979), The Process is the Punishment, New York: Russell Sage.

Feeley, M. (1982), 'Plea bargaining and the structure of the criminal process', Journal of Justice Systems, 73: 338. 
Feinberg, J. (1992), 'In defence of moral rights', Oxford Journal of Legal Studies, 12: 149.

Fenwick, H. (1997), 'Procedural "rights" of victims of crime: public or private ordering of the criminal process?', Modern Law Review, 60(3): 317.

Ferguson, G. and D. Roberts (1974), 'Plea bargaining: directions for Canadian reform', Canadian Bar Review, 52: 498.

Fields, P. (2008), 'Case comment. Clarke and McDaid: a technical triumph', Criminal Law Review, 8: 612-24.

Fine, B. and R. Millar (eds) (1985), Policing the Miners, London: Lawrence \& Wishart.

Finkelstein, M. (1975), 'A statistical analysis of guilty plea practices in the Federal Courts', Harvard Law Review, 89: 293.

Fisher, Sir Henry (1977), Report of an Inquiry by the Hon. Sir Henry Fisher into the circumstances leading to the trial of three persons on charges arising out of the death of Maxwell Confait and the fire at 27 Doggett Road, London SE 6, London: HMSO.

Fitzgerald, M. (1993), Ethnic Minorities and the Criminal Justice System, Royal Commission on Criminal Justice Research Study No. 20, London: HMSO.

Flanagan, R. (2008), The Review of Policing: Final Report, London: Home Office.

Foot, P. (1986), Murder at the Farm, London: Sidgwick \& Jackson.

Foucault, M. (1978), The History of Sexuality (ed. Robert Hurley), London: Allen Lane.

Franey, R. (1983), Poor Law, London: CHAR, CPAG, CDC, NAPO, NCCL.

Frey, R. (1980), Interests and Rights: The Case Against Animals, Oxford: Clarendon Press.

Fuller, L. (1961), 'The adversary system', in H.J. Berman (ed.), Talks on American Law, New York: Vintage Books.

Fuller, L. (1978), 'The forms and limits of adjudication', Harvard Law Review, 92(2): 353.

Garden Court Chambers (2012), 'Sean Rigg Inquest report', 2 August, available at: http://www.gardencourtchambers.co.uk/news/news_detail. cfm? iNewsID $=759$

Garfinkle, H. (1955), 'Conditions of successful degradation ceremonies', American Journal of Sociology, 61: 420.

Garrett, B. (2008), 'Judging Innocence', Columbia Law Review, 108: 55.

Gee, J. and M. Button (2013), The Financial Cost of Fraud Report 2013, University of Portsmouth: Centre for Counter Fraud Studies.

Genders, E. (1999), 'Reform of the Offences Against the Person Act: Lessons from the Law in Action', Criminal Law Review, 689. 
Gibson, J. (2006), 'Judicial institutions', in R. Rhodes, S. Binder and B. Rockman (eds), The Oxford Handbook of Political Institutions, Oxford: Oxford University Press.

Golding, P. and S. Middleton (1982), Images of Welfare: Press and Public Attitudes to Poverty, Oxford: Martin Robertson.

Gordon, G. (1970), 'Plea Bargaining', The Scots Law Times, 2 October: 153.

Goriely, T. et al. (2001), The Public Defence Solicitors Office in Edinburgh: An Independent Evaluation, Scottish Executive Council Research Unit/ TSO.

Grayling, C. (2013), 'UK set to host 2015 Global Law Summit', Government Press Release, 6 October, available at: https://www.gov.uk/government/ news/uk-set-to-host-2015-global-law-summit

Green, P. (1990), Policing the Miners' Strike, Milton Keynes: Open University Press.

Greer, S. (1995), Supergrasses: A Study in Anti-Terrorism Law Enforcement in Northern Ireland, Oxford: Clarendon Press.

Gregory, J. (1976), Crown Court or Magistrates' Court, Office of Population and Censuses and Surveys, London: HMSO.

Gregory, W., J. Mowen and D. Linder (1978), 'Social psychology and plea bargaining', Journal of Personality and Social Psychology, 36: 1521.

Gross, Rt Hon LJ and Treacy, Rt Hon LJ (2012), Further Review of Disclosure in Criminal Proceedings, Judiciary of England and Wales.

Gross, S., R. Jacoby, K. Matheson and D.J. Montgomery (2005), 'Exonerations in the United States, 1989 through 2003', Journal of Criminal Law \& Criminology, 95: 523.

Guardian/LSE (2011), Reading the Riots: Investigating England's Summer of Disorder, London: Guardian/LSE.

Guest, S. (2009), 'How to criticize Dworkin's Theory of Law', Analysis, 69(2): 1.

Hall, A. (2010), 'Where do the advocates stand when the goalposts are moved?', International Journal of Evidence \& Proof, 14: 107.

Hamlyn, B., A. Phelps, J. Turtle and G. Sattar (2004), Are Special Measures Working? Evidence from Surveys of Vulnerable and Intimidated Witnesses, Home Office Research Study No. 283, Home Office, Research Development and Statistics Directorate.

Harman, H. and J. Griffith (1979), Justice Deserted: The Subversion of the Jury, London: National Council for Civil Liberties.

Harper, R. and A. McWhinnie (1983), The Glasgow Rape Case, London: Hutchinson.

Harries, R. (1999), The Cost of Criminal Justice, Home Office Research Directorate, No. 103.

Harris, J. and S. Grace (1999), A Question of Evidence? Investigating and 
Prosecuting Rape in the 1990s, Home Office Research Study No.196, London: Home Office.

Hedderman, C. and D. Moxon (1992), Magistrates' Court or Crown Court? Mode of Trial Decisions and Sentencing, Home Office Research Study No. 125, London: HMSO.

Heilbroner, D. (1990), Rough Justice: Days and Nights of a Young D.A., New York: Pantheon Books.

Henham, R. (1999), 'Bargain justice or justice denied? Sentence discounts and the criminal process', Modern Law Review, 62(4): 515.

Henham, R. (2002), 'Further evidence on the significance of plea in the crown court', Howard Journal of Criminal Justice, 41: 151.

Heumann, M. (1975), 'A note on plea bargaining and case pressure', Law and Society Review, 9: 515.

Heumann, M. (1978), Plea Bargaining, Chicago: University of Chicago Press.

Heydon, J. (2013), 'Threats to judicial independence: the enemy within', Law Quarterly Review, 129: 205.

Hilbery, M. (1975), Duty and Art in Advocacy, London: Stevens.

Hillyard, P. (1994), 'The politics of criminal justice: the Irish dimension', in M. McConville and L. Bridges (eds), Criminal Justice in Crisis, Aldershot, UK and Brookfield, VT, USA: Edward Elgar.

HM Crown Prosecution Service Inspectorate (HMCPSI) (2003), Thematic Review of Attrition in the Prosecution Process (the Justice Gap), London: HMCPSI.

HM Crown Prosecution Service Inspectorate (HMCPSI) (2004), Violence at Home: A Joint Thematic Inspection of the Investigation and Prosecution of Cases Involving Domestic Violence, London: HMCPSI.

HM Crown Prosecution Service Inspectorate (HMCPSI) (2007), Discontinuance (Thematic Review), London: HMCPSI.

HM Crown Prosecution Service Inspectorate (HMCPSI) (2012a), CPS London: Follow-up Report, London: HMCPSI.

HM Crown Prosecution Service Inspectorate (HMCPSI) (2012b), CPS Gwent and CPS South Wales: Follow-up Inspection, March, available at: http://www.hmcpsi.gov.uk/documents/reports/AEI/GWSW/WALS_ FU_GWN_SWA_Mar12_rpt.pdf

HM Crown Prosecution Service Inspectorate (HMCPSI) (2012c), CPS Core Quality Standards Monitoring Scheme: Thematic Review of the CPS Core Quality Standards Monitoring Scheme, London: HMCPSI.

HM Crown Prosecution Service Inspectorate (HMCPSI) (2012d), Follow Up Report of the Thematic Review of the Quality of Prosecution Advocacy and Case Presentation, London: HMCPSI. 
HM Inspectorate of Constabulary (HMIC) (2013a), Stop and Search Powers: Are the Police Using Them Effectively and Fairly? 9 July.

HM Inspectorate of Constabulary (HMIC) (2013b), South Yorkshire Police's Response to Child Sexual Exploitation, 11 November.

HM Inspectorate of Constabulary (HMIC) (2013c), Crime Recording in Kent: A Report Commissioned by the Police and Crime Commissioner for Kent, 17 June.

HM Inspectorate of Constabulary and HM Crown Prosecution Service Inspectorate (2011), A New Approach to Tackling Offending in Communities Needed, London: Criminal Justice Joint Inspection.

Home Affairs Committee (2013), Eleventh Report, 2012-2013 on the Independent Police Complaints Commission, HC 494, 1 February.

Home Office (1963), Sheffield Police Appeal Inquiry, Cmnd 2176, London: HMSO.

Home Office (1992), Costs of the Criminal Justice System 1992, Vol. 1, London: Home Office.

Home Office (2002), Justice for All, Cm 5563, London: Home Office.

Home Office (2004), Analysis of Ethnic Minority Deaths in Police Custody, London: HMSO.

Home Office (2011), An Overview of Recorded Crimes and Arrests Resulting from Disorder Events in August 2011, October.

Home Office (2012), Police Powers and Procedures, England and Wales 2010/11: Second Edition (Stop and Searches), 19 April.

Hodgson, J. (2005), French Criminal Justice, Oxford: Hart Publishing.

Hodgson, J. (2006), 'The Role of the Criminal Defence Lawyer in an Inquisitorial Procedure: Legal and Ethical Constraints', Legal Ethics, 9(1): 125.

Hodgson, J. (2010), 'The future of adversarial criminal justice in 21st century Britain', North Carolina Journal of International Law and Commercial Regulation, 35: 319.

Hoffman, L. (1964), 'The Judges' Rules', Lawyer, 7: 23.

Hohl, K. (2011), 'The role of mass media and police communication in trust in the police: new approaches to the analysis of survey and media data', PhD thesis, LSE, available at: http://etheses.lse.ac.uk/213/

Honess, T., M. Levi and E. Charman (1998), 'Juror competence in processing complex information: implications from a simulation of the Maxwell Trial', Criminal Law Review, 763.

Honess, T., M. Levi and E. Charman (2003), 'Juror competence in serious frauds since Roskill: a research-based assessment', Journal of Financial Crime, 11(1): 17.

Hood, R. (1992), Race and Sentencing, Oxford: Oxford University Press. Houlden, P. and S. Balkin (1985), 'Quality and cost comparisons of private 
bar indigent defense systems: contract vs. ordered assigned counsel', Journal of Criminal Law and Criminology, 76: 177.

House of Commons (1995), Hansard, First Scottish Standing Committee, Col. 556, 4 April.

House of Commons (2005), 'Terrorism and community relations, sixth report of sessions 2004-2005', Home Affairs Select Committee, Vol.1, HC 165-1, London: TSO.

House of Commons (2013a), Hansard (Debate), Col. 116, 5 February.

House of Commons (2013b), Hansard (Debate), Col. 523, 27 June.

House of Commons (2013c), Hansard (Debate), Cols 75-77WH, 4 September.

Howitt, D. (1998), Crime, the Media and the Law, West Sussex: Wiley.

Hucklesby, A. (1997), 'Remand decision makers', Criminal Law Review, 269.

Hughes, E. (1971), The Sociological Eye, Chicago: Aldine-Atherton.

Human Rights Watch (2010), Without Suspicion: Stop and Search Under the Terrorism Act 2000, London: Human Rights Watch.

Hyde, D. (2010), 'Tax evasion costs the Treasury 15 times more than benefit fraud', Citywire Money, available at: http:/citywire.co.uk/money/ tax-evasion-costs-treasury-15-times-more-than-benefit-fraud/a378274

Hyde, J. (2013), 'Grieve: legal aid cuts hurt, but bar is just too big', Law Society Gazette, 30 September.

Independent Police Complaints Commission (IPCC) (2012), Corruption in the Police Service in England and Wales: Second Report - a report based upon the IPCC's experience from 2008 to 2011, London: The Stationery Office.

Independent Police Complaints Commission (IPCC) (2013), Southwark Sapphire Unit's Local Practices for the Reporting and Investigation of Sexual Offences, July 2008-September 2009 - Independent Investigation Learning Report, February.

Institute of Race Relations (1987), Policing Against Black People, London: Institute of Race Relations.

Ip, J. (2013), 'The reform of counterterrorism stop and search after Gillan v. United Kingdom', Human Rights Law Review, 13(1): 1.

Jackson, J. (1993), 'Trial procedures', in C. Walker and K. Starmer (eds), Justice in Error, London: Blackstone Press.

Jackson, J. (1996), 'Judicial responsibility in criminal proceedings', Current Legal Problems, 49(1): 59.

Jackson, J. and S. Doran (1995), Judge Without Jury, Oxford: Oxford University Press.

James Committee (1975), The Distribution of Criminal Business between the Crown Court and the Magistrates' Court, Cmnd. 6323.

Jeremy, D. (2008), 'The prosecutor's rock and hard place', Criminal Law Review, 925. 
Jones, R. (2009), 'From Orgreave to the City', Red Pepper, June.

Judge, Lord (2011), 'Summary justice in and out of court', John Harris

Memorial Lecture, available at: http:/www.judiciary.gov.uk/media/ speeches/2011/lcj-speech-john-harris-memorial-lecture-07072011

Judicial Executive Board (2013), Response to the Ministry of Justice Transforming Legal Aid Consultation, June, available at: http://www. judiciary.gov.uk/Resources/JCO/Documents/Consultations/jeb-respon se-reform-legal-aid-june-2013.pdf

Judiciary of England and Wales (2013), Response of the Judicial Executive Board to the Government's Consultation Paper CP14/2013,Transforming Legal Aid: Delivering a More Credible and Efficient System, June.

JUSTICE (1971), The Unrepresented Defendant in Magistrates' Courts, London: Stevens \& Sons.

Kalsi, S. (2011), 'August riots - the legal aftermath', 3 October, available at: http://www.law.ac.uk/august-riots/

Kee, R. (1986), Trial and Error, London: Hamish Hamilton.

Kelly, L., J. Lovett and L. Regan (2005), Gap or Chasm? Attrition in Reported Rape Cases, Home Office Research Study No. 293, London: Home Office.

Kemp, V. (2010), Transforming Legal Aid: Access to Criminal Defence Services, London: Legal Services Research Centre.

Kennedy, L. (1990), On My Way to the Club, London: Fontana.

Kettle, M. and L. Hodges (1982), Uprising, London: Pan Books.

King, M. (1971), Bail or Custody, London: The Cobden Trust.

King, M. and C. May (1985), Black Magistrates, London: Cobden Trust.

Kipnis, K. (1979), 'Plea bargaining: a critic's rejoinder', Law \& Society Review, 13(2): 555.

Labour Party (2005), Tackling Crime: Forwards Not Back, Labour Party, UK. Lacey, N. (1994), 'Missing the wood . . pragmatism versus theory in the Royal Commission', in M. McConville and L. Bridges (eds), Criminal Justice in Crisis, Aldershot, UK and Brookfield, VT, USA: Edward Elgar.

Langer, M. (2005), 'The rise of managerial judging in international criminal law', American Journal of Comparative Law, 835.

Law Society (2013), Response to the Ministry of Justice Transforming Legal Aid Consultation, June, available at: http://www.lawsociety.org.uk / representation / policy-discussion / transforming-legal-aid-consultationlaw-society-response/

Lea, J. and S. Hallsworth (2012), 'Understanding the riots', Criminal Justice Matters, 87(1): 30.

Lea, S., U. Lanvers and S. Shaw (2003), 'Attrition in rape cases', British Journal of Criminology, 43: 583.

Lefstein, N. (1982), Criminal Defense Services for the Poor: Methods and 
Programs for Providing Legal Representation and the Need for Adequate Financing, Chicago, IL: American Bar Association.

Leigh, L. (2013), 'Cautioning - whatever happened to common sense?', Criminal Law \& Justice, 177: 269.

Leipond, A. (2005), 'How the pre-trial process contributes to wrongful convictions', American Criminal Law Review, 42: 1123.

Leishman, F. and P. Mason (2003), Policing and the Media: Facts and Fictions, Cullompton: Willan Publishing.

Leon, H.C. (1970), The English Judge, The Hamlyn Lectures, London: Stevens and Sons.

Leverick, F. (2004), 'Tensions and balances, costs and rewards: the sentence discount in Scotland', Edinburgh Law Review, 8(3): 360.

Leverick, F. (2006), 'Plea and confession bargaining in Scotland', Electronic Journal of Comparative Law, 10(3) December, available at: http://www. ejcl.org/103/art103-8.pdf

Leverick, F. (2012), 'Sentence discounting for guilty pleas: a question of guidelines', Edinburgh Law Review, 16(2): 233.

Leveson Report (2012), 'An Inquiry into the Culture, Practice and Ethics of the Press', UK: TSO, 29 November, available at: http://www.official documents.gov.uk/document/hc1213/hc07/0780/0780.asp

Levi, M. (1993), The Investigation, Prosecution and Trial of Serious Fraud, Royal Commission on Criminal Justice, Research Study No.14.

Levitt, A. and the Crown Prosecution Service Equality and Diversity Unit (2013), Joint Report - Charging Perverting the Course of Justice and Wasting Police Time in Cases Involving Allegedly False Rape and Domestic Violence Allegations, March.

Lewis, P. and R. Evans (2013), Undercover: The True Story of Britain's Secret Police, London: Faber and Faber.

Lippke, R. (2011), The Ethics of Plea Bargaining, Oxford: Oxford University Press.

Lloyd-Bostock, S. (2007), 'The Jubilee Line jurors: does their experience strengthen the argument for judge-only trial in long and complex fraud cases?', Criminal Law Review, 255.

Lord Chancellor's Department (2001), Code of Conduct for Employees of the Legal Services Commission who Provide Services as Part of the Criminal Defence Service, London: The Stationery Office.

Lynch, D. (1994), 'The impropriety of plea agreements: a tale of two counties', Law and Social Inquiry, 19(1): 115.

Mack, K. and S. Anleu (1997), 'Sentence discount for a guilty plea: time for a new look', Flinders Journal of Law Reform, 1: 123.

Magistrate (2011), 'Stop delaying justice! A new training programme', 67(9): 6. 
Mansfield, M. (2009), Memoirs of a Radical Lawyer, London: Bloomsbury Press.

Mark, Sir Robert (1973), Minority Verdict, London: BBC Publications.

Martin, R. (2013), 'The recent supergrass controversy: have we learnt from the troubled past?', Criminal Law Review, 4: 273.

McBarnet, D. (1978), 'The Fisher Report on the Confait case: four issues', Modern Law Review, 41: 455.

McBarnet, D. (1983), Conviction: Law, the State and the Construction of Justice, 2nd edn, London: Macmillan.

McCabe, S. and R. Purves (1972), By-passing the Jury: A Study of Changes of Plea and Directed Acquittals in Higher Courts, Oxford: Blackwell for the Oxford University Penal Research Unit.

McConville, M. (1992), 'Videotaping interrogations: police behaviour on and off camera', Criminal Law Review, 532.

McConville, M. and J. Baldwin (1981), Courts, Prosecution and Conviction, London: Oxford University Press.

McConville, M. and L. Bridges (1993a), 'Pleading guilty whilst maintaining innocence', New Law Journal, 143: 160.

McConville, M. and L. Bridges (1993b), 'Guilty pleas and the politics of research', Legal Action, 9 April.

McConville, M. and C. Mirsky (1993a), 'The disordering of criminal justice', New Law Journal, 143: 1446.

McConville, M. and C. Mirsky (1993b), 'To plea or not to plea', Legal Action, February.

McConville, M. and C. Mirsky (1995), 'Guilty plea courts: a social disciplinary model of criminal justice', Social Problems, 42(2): 216.

McConville, M. and C. Mirsky (2005), Jury Trials and Plea Bargaining, Oxford: Hart.

McConville, M. and P. Morrell (1983), 'Recording the interrogation: have the police got it taped?', Criminal Law Review, 158.

McConville, M. and E. Pils (eds) (2013), Comparative Perspectives on Criminal Justice in China, Cheltenham, UK and Northampton, MA, USA: Edward Elgar.

McConville, M. and D. Shepherd (1992), Watching Police Watching Communities, London: Routledge.

McConville, M., J. Hodgson, L. Bridges and A. Pavlovic (1994), Standing Accused, Oxford: Clarendon Press.

McConville, M., A. Sanders and R. Leng (1991), The Case for the Prosecution, London: Routledge.

McConville, M. et al. (2011), Criminal Justice in China: An Empirical Inquiry, Cheltenham, UK and Northampton, MA, USA: Edward Elgar. 
McEwan, J. (2011), 'From adversarialism to managerialism: criminal justice in transition', Legal Studies, 31(3): 519.

McEwan, J. (2013), 'Truth, efficiency, and cooperation in modern criminal justice', Current Legal Problems, 66(1): 203-32.

McEwan, J. and F. Garland (2012), 'Embracing the overriding objective: difficulties and dilemmas in the new criminal climate', International Journal of Evidence and Proof, 16(3): 233.

McInnes Report (2004), Report of the Summary Justice Review Committee: Report to Ministers, 16 March.

McKenna, Mr Justice (1970), 'Police interrogation', New Law Journal, 16 July, 120.

Metropolitan Police Service (2012), Strategic Review into the Disorders of August 2011 - Final Report, London.

Mill, J.S. (1861), On Representative Government, London: Parker, Son and Bourn.

Miller, J. (2003), Police Corruption in England and Wales: An Assessment of Current Evidence, Home Office, Online Report 11/03.

Miller, J., N. Bland and P. Quinton (2000), The Impact of Stops and Searches on Crime and the Community, Home Office Research Paper No. 127, London: Home Office.

Ministry of Justice (2005), The Criminal Procedure Rules and Criminal Practice Directions, London: Ministry of Justice, available at: http:// www.legislation.gov.uk/uksi/2013/1554/contents/made

Ministry of Justice (MoJ) (2011a), Statistical Bulletin on the Public Disorder of 6th to 9th August 2011, London: Ministry of Justice.

Ministry of Justice (MoJ) (2011b), Judicial and Court Statistics 2010, 30 June, 2011 (revised July 2011), London: Ministry of Justice.

Ministry of Justice (MoJ) (2012a), Statistical Bulletin on the Public Disorder of 6th to 9th August 2011 - February 2012 Update, London: Ministry of Justice.

Ministry of Justice (MoJ) (2012b), Judicial and Court Statistics 2011, 28 June, London: Ministry of Justice.

Ministry of Justice (MoJ) (2012c), Swift and Sure Justice: The Government's Plans for Reform of the Criminal Justice System, Cm8388, 12 July, London: HMSO.

Ministry of Justice (MoJ) (2013a), Criminal Justice Statistics, Quarterly Update to December 2012, 30 May, London: Ministry of Justice.

Ministry of Justice (MoJ) (2013b), Consultation Paper CP 14/2013. Transforming Legal Aid: Delivering a More Credible and Efficient System, 9 April, London: Ministry of Justice.

Ministry of Justice (MoJ) (2013c), Statistics on Race and the Criminal Justice System 2012, November, London: Ministry of Justice. 
Ministry of Justice (MoJ) (2013d), Annual Reports and Accounts 2012-13, 25 June, London: Ministry of Justice.

Ministry of Justice (MoJ) (2013e), Her Majesty's Court and Tribunal Service Statistics, September, London: Ministry of Justice.

Mitchell, B. (2011), 'Sentencing riot-related offending: considering Blackshaw and others', Archbold Review, 10: 4.

Moody, S. and J. Tombs (1982), Prosecution in the Public Interest, Edinburgh: Scottish Academic Press.

Morton, J. (1977), 'Trial by blacklist', New Law Journal, 127: 280.

Morton, J. (1993), Bent Coppers, London: Warner Books.

Moss, N. (2013), Every Case, A Managed Case: Using The Criminal Procedure Rules Speech to London CPS, 5 March, available at: http:// www.judiciary.gov.uk / Resources / JCO / Documents/Speeches/nicholasmoss-speech-cps-london-050313.pdf

Moxon, D. (1988), Sentencing Practice in the Crown Court, Home Office Research Study No. 103, London: HMSO.

Mulcahy, A. (1994), 'The justifications of "Justice", British Journal of Criminology, 34: 411.

Mullin, C. (1986), Error of Judgement: The Truth about the Birmingham Bombings, London: Chatto \& Windus.

Murray, K. (2014), 'Stop and search in Scotland: an evaluation of police practice', The Scottish Centre for Crime \& Justice Research, University of Edinburgh, January.

Nardulli, P. (1979), 'The caseload controversy and the study of criminal courts', Criminal Law \& Criminology, 70: 89.

National Audit Office (2009), The Procurement of Criminal Legal Aid in England and Wales by the Legal Services Commission, 27 November, London: The Stationery Office.

National Audit Office (1992), The Ministry of Justice's Language Service Contract, Memorandum, 10 September 1992, available at: http://www. nao.org.uk/

Naughton, M. (ed.) (2010), The Criminal Cases Review Commission: Hope for the Innocent?, Basingstoke: Palgrave.

Neuberger, Lord (2013), 'Justice in an Age of Austerity', JUSTICE: Tom Sargant Memorial Lecture 2013, 15 October, available at: http:// www.justice.org.uk/data/files/resources/357/Neuberger-2013-lecture. pdf

Newburn, T., M. Shiner and S. Hayman (1994), 'Race, crime and injustice: strip search and the treatment of suspects in police custody', British Journal of Criminology, 34: 677.

New Law Journal (1970), 'Comment. Plea bargaining - conflicts of interest', New Law Journal, 19 March. 
New Law Journal (1970), 'Guilty pleas: counsel's role', New Law Journal, 30 April.

New Law Journal (1975), 'Right to counsel', New Law Journal, 13 February.

Newman, D. (2013), Legal Aid Lawyers and the Quest for Justice, Oxford: Hart Publishing.

Nicholson, D. (2013), 'Taking epistemology seriously: "truth, reason and justice” revisited', International Journal of Evidence \& Proof, 17(1): 1.

Ormerod, D. (2012), Blackstone's Criminal Practice, 22nd edn, 2011, Oxford: Oxford University Press.

Orwell, G. (1945), 'Notes about nationalism', first published, London: Polemic.

Oxford Economics (2014), Forecasting Criminal Legal Aid Expenditure, January, Oxford, UK.

Padfield, N. (2013), 'Transforming legal aid', Archbold Review, 5: 5.

Parnas, R.I. and R.J. Atkins (1978), 'The elimination of plea bargaining: a proposal', Criminal Law Bulletin, 14: 101.

Pattenden, R. and L. Skinns (2010), 'Choice, privacy and publicly-funded legal advice at police stations', Modern Law Review, 73: 349.

Percy-Smith, J. and P. Hillyard (1985), 'Miners in the arms of the law: a statistical analysis', Journal of Law and Society, 12(3): 345.

Phillips, C. and D. Brown (1998), Entry into the Criminal Justice System: A Survey of Police Arrests and their Outcomes, Home Office Research Study No. 185, London: Home Office Research and Statistics Directorate.

Poland, Sir H.B. (1898), Short History of the Criminal Evidence Act, Mr. Baugh Allen's edition of the Act [originally cited in Rogers (1899)].

Ponting, C. (1987), 'R v Ponting', Journal of Law and Society, 14(3): 366.

Rauxloh, R. (2012), Plea Bargaining in National and International Law, Abingdon: Routledge.

Rawls, J. (1972), A Theory of Justice, Cambridge: Harvard University Press.

Reiner, R. (1985), The Politics of the Police, Brighton: Wheatsheaf Books.

Rhodes, D. (2013), 'Life in Crime: "Degrees of separation", Solicitor's Journal, 157(12), 26 March.

Richards, P., E. Richards, C. Devon, S. Morris and A. Mellows-Facer (2011a), Summary Justice Reform: Evaluation of Fiscal Work Order Pilots, Scottish Government Social Research, available at: http://www. scotland.gov.uk/Publications/2011/01/24140850/0

Richards, P., E. Richards, C. Devon, S. Morris and A. Mellows-Facer (2011b), Summary Justice Reform: Evaluation of Direct Measures, Scottish Government Social Research, Morris Richards Ltd. 
Richardson, J. (2011), 'A "just" outcome: losing sight of the purpose of criminal procedure', Journal of Commonwealth Criminal Law, 105.

Richardson, J. (2013), 'Is the criminal appeal system fit for purpose?', Criminal Law Week, Issue 19, 20 May.

Risinger, D. (2007), 'Innocents convicted: an empirically justified factual wrongful conviction rate', Journal of Criminal Law \& Criminology, 97: 761.

Roberts, A. (2012), 'Case comment: Nunn v Chief Constable of Suffolk Constabulary: evidence - prosecution evidence - disclosure', Criminal Law Review, 12: 968.

Roberts, D. (1993), 'Questioning the suspect: the solicitor's role', Criminal Law Review, 368.

Roberts, J. (2012), 'Points of departure: reflections on sentencing outside the definitive guidelines ranges', Criminal Law Review, 6: 439.

Robertson, G. (2013), Stephen Ward Was Innocent OK: The Case for Overturning His Conviction, London: Biteback Publishing.

Robson, G. (2012), 'Swift and sure justice? Here we go again', Criminal Law \& Justice Weekly, 7 September.

Roche, M. (1992), Rethinking Citizenship: Welfare, Ideology and Change in Modern Society, Cambridge: Polity Press.

Rogers, S. (1899), 'The ethics of advocacy', Law Quarterly Review, 15: 259.

Romily, S. (1810), Observations on the Criminal Law of England, Note D.

Rose, G. (1967), Special Statistical Survey, Table 22, in Royal Commission on Assizes and Quarter Sessions, 1966-1969, (1971) Cmnd. 4153.

Rose, G. (1971), Royal Commission on Assizes and Quarter Sessions 196669. Special Statistical Survey, London: HMSO.

Roskill, Lord (1986), Fraud Trials Committee, London: HMSO.

Rowntree, S. (1901), Poverty: A Study in Town Life, London: Macmillan.

Royal Commission on Criminal Justice (RCCJ) (1993), Report, Cm 2263, London: HMSO.

Royal Commission on Criminal Procedure (RCCP) (1981), Report, Cmnd. 8092, London: HMSO.

Royal Commission on Police Powers and Procedure (RCPPP) (1929), Report, Cmd. 3297.

Rozenberg, J. (2014), Lord Chief Justice elps politicians grasp courts' 'hot potato', The Guardian, 4 March, 2014).

Rumney, P. (2006), 'False allegations of rape', Cambridge Law Journal, 65(1): 12 .

Sanders, A. (1979), 'Guilt, innocence and jury acquittals', Howard Journal of Criminal Justice, 24: 76.

Sanders, A. and R. Young (2007), Criminal Justice, 3rd edn, Oxford: Oxford University Press. 
Sanders, A. and R. Young with M. Burton (2010), Criminal Justice, 4th edn, Oxford: Oxford University Press.

Sanders, A., L. Bridges, A. Mulvaney and G. Crozier (1989), Advice and Assistance at Police Stations and the 24-Hour Duty Solicitor Scheme, London: Lord Chancellor's Department.

Sandham, J. (1983), 'Operation Major: a backward glance', Probation Journal, 30: 29.

Scanlon, T.M. (1999), What We Owe to Each Other, Cambridge MA: Belknap Press.

Scarman, Lord (1981), The Brixton Disorders, 10-12th April, London: HMSO.

Scheck, B., P. Neufeld and J. Dwyer (2000), Actual Innocence: Five Days to Execution and Other Dispatches from the Wrongly Convicted, New York: Doubleday.

Schulhofer, S. (1986), 'Effective assistance on the assembly line', New York University Review of Law and Social Change, 14: 137.

Schulhofer, S. (1992), 'Plea bargaining as disaster', Yale Law Journal, 101: 1979.

Scott, R. and W. Stuntz (1992), 'Plea bargaining as contract', Yale Law Journal, 101: 1909.

Scottish Executive (2003), Modernising Justice in Scotland: The Reform of the High Court of Justiciary, Edinburgh: Scottish Government.

Scottish Office (1993), Improving the Delivery of Justice in Scotland: 1993 Review of Criminal Evidence and Procedure, Great Britain: Scottish Office.

Scottish Office (1994), Firm and Fair, CM 2600, Edinburgh: HMSO.

Scraton, P. (1985), The State of the Police, London: Pluto Press.

Scraton, P. (2012), The Report of the Hillsborough Independent Panel, HC 581, London: The Stationery Office.

Scraton, P. (2013), 'The legacy of Hillsborough: liberating truth, challenging power', Race \& Class, 55(2): 1.

Seabrook, R. (1992), The Efficient Disposal of Business in the Crown Court, London: The General Council of the Bar.

Sedley, S. (2011), Ashes and Sparks: Essays on Law and Justice, Cambridge: Cambridge University Press.

Seifman, R. (1980), 'Plea bargaining in England', in W. McDonald and J. Cramer (eds), Plea Bargaining, Lexington Books: D.C. Heath.

Sentencing Guidelines Council (2007), Reduction in Sentence for a Guilty Plea: Definitive Guideline (Sentencing Guidelines Secretariat, revised July).

Shapiro, D. (1984), 'Should a guilty plea have preclusive effect?', Iowa Law Review, 70: 27. 
Shattuck, P. (1974), 'Law as politics', Comparative Politics, 7(1) (October): 127.

Shead, C. (2013), 'The decision in Murray v HM Advocate', Scottish Criminal Law, February: 93.

Shearing, C. (1981), 'Subterranean processes in the maintenance of power: an examination of the mechanisms coordinating police action', Canadian Review of Sociology and Anthropology, 18(3): 283.

Sheskin, A. (1981), 'Trial courts on trial: examining dominant assumptions', in J.A. Cramer (ed.), Courts and Judges, Beverly Hills, CA: Sage Publications.

Shiner, M. (2012), Report on the Use of Section 60 of the Criminal Justice and Public Order Act 1994 by the Police, February, availableat:http://www.stopwatch.org/uploads/documents/Shiner_expertwitnessstatement_s60. pdf

Singh, D., S. Marcus, H. Rabbatts and M. Sherlock (2012), After the Riots - the Final Report of the Riots Communities and Victims Panel, March.

Skinns, L. (2009), “I'm a detainee; get me out of here": predictors of access to custodial legal advice in public and privatized police custody areas in England and Wales', British Journal of Criminology, 49(3): 399.

Skinns, L. (2011), 'The right to legal advice in the police station: past, present and Future', Criminal Law Review, 19.

Slater, E. (2012), 'Scrutinising government - a case to answer: The return of the Supergrass', 7 October, The Bureau of Investigative Journalism, available at: http://www.thebureauinvestigates.com/2012/ 10/07/the-return-of-the-supergrass/

Smith, D. (1983), Police and People in London: A Survey of Police Officers, London: Policy Studies Institute.

Smith, P. and P. Thomas (1985), Striking Back, Cardiff: Welsh Campaign for Civil and Political Liberties.

Smith,R.(2011), 'LegalaidinEnglandand Wales:enteringtheendgame',ILAG Newsletter, May, available at: http://www.ilagnet.org/newsletterstories. php?id $=37$

Smith, T. (2013a), 'The "quiet revolution" in criminal defence: how the zealous advocate slipped into the shadow', International Journal of the Legal Profession, 20(1): 111.

Smith, T. (2013b), 'Trust, choice and money: why the legal aid reform "uturn" is essential for effective criminal defence', Criminal Law Review, 11: 906.

Spector, M. and J. Kitsuse (2001), Constructing Social Problems, New Brunswick, NJ: Transaction Publishers.

Stedman Jones, G. (1971), Outcast London, Oxford: Clarendon Press. 
Stewart Committee Report (1983), Keeping Offenders Out of Court: Further Alternatives to Prosecution, 2nd Report, Cmnd. 8958, HMSO.

Steyn, Lord (1997), 'The Weakest and Least Dangerous Department of Government', Public Law, 84.

Storch, R. (1976), 'The policeman as domestic missionary: urban discipline and popular culture in northern England 1850-1880', Journal of Social History, IX: 4.

Tata, C. (2007), 'In the interests of commerce or clients? Legal aid, supply, demand, and ethical indeterminacy in criminal defence work', Journal of Law and Society, 34(4): 489.

Tata, C. (2010), 'Sentencing and penal decision-making: is Scotland losing its distinctive character?', in H. Croall, G. Mooney and M. Monro (eds), Criminal Justice in Scotland, Oxford: Willan Publishing.

Tata, C. and F. Stephen (2006), "Swings and roundabouts": do changes to the structure of legal aid make a real difference to criminal case outcomes?', Criminal Law Review, 46: 722.

Thomas, G.C. (2010), 'Two windows into innocence', Ohio State Journal of Criminal Law, 7: 575.

Thomas, P.A. (1978), 'Plea bargaining in England', The Journal of Criminal Law \& Criminology, 69(2): 170.

Thomas, P.A. (1982), 'Royal Commissions', Statute Law Review, Spring: 40.

Thomas, P.A. and G. Mungham (1976), A Report on the Duty Solicitor Scheme Operating in the Cardiff Magistrates' Court, Cardiff: University College.

Thomas, P.A. and G. Mungham (1977), 'Duty solicitor schemes: in whose interest?' New Law Journal, 127: 180.

Thomas, R.M. (1986), 'The British Official Secrets Acts 1911-1939 and the Ponting case', Criminal Law Review, 491.

Thomas of Cwmgiedd, Lord (2014), 'Reshaping Justice', Speech delivered to JUSTICE, 3 March, available at: http://www.judiciary.gov.uk/ Resources/JCO/Documents/Speeches/lcj-speech-reshaping-justice.pdf

Thompson, E.P. (1971), 'The moral economy of the English crowd in the eighteenth century', Past and Present, 50(1): 76.

Thomson, D. (2004), 'Discount of sentencing following a guilty plea', Scots Law Times, 1.

Tonry, M. (2004), Punishment and Politics, Cullompton: Willan.

Travers, M. (1997a), 'Preaching to the converted? Improving the persuasiveness of criminal justice research', British Journal of Criminology, 37: 359.

Travers, M. (1997b), The Reality of Law: Work and Talk in a Firm of Criminal Lawyers, Aldershot: Ashgate. 
Vennard, J. (1982), Contested Trials in Magistrates' Courts, Home Office Research Study No. 71, London: HMSO.

Verdun-Jones, S. and A. Hatch (1988), Plea Bargaining and Sentence Guidelines, Ottawa: Department of Justice Canada.

Von Hirsch, A., A. Bottoms, E. Burney and P-O. Wikstrom (1999), Criminal Deterrence and Sentence Severity: An Analysis of Recent Research, Oxford: Hart Publishing.

Walchover, D. (1989), 'Should judges sum up on the facts?', Criminal Law Review, 781.

Walker, C. (2002), 'Miscarriages of justice and the correction of error', in M. McConville and G. Wilson (eds), The Handbook of the Criminal Justice Process, Oxford: Oxford University Press.

Walker, C. (2006), 'Case comment: $R$. (on the application of Gillan) $v$ Commissioner of Police of the Metropolis [2006] UKHL 12; [2006] 2 A.C. 307 (HL)', Criminal Law Review, August: 751.

Ward, T. (1986), Death and Disorder, London: Pluto Press.

White, R. (2008), 'Out of court and out of sight', Edinburgh Law Review, 12(3): 481.

Whitton, E. (1988), The Cartel: Lawyers and their Nine Magic Tricks, Australia: E \& N Whitton.

Wigmore, J.H. (1940), Treatise on the Anglo-American System of Evidence in Trials at Common Law, 3rd edn, Boston: Little, Brown.

Williams, C. (2012), 'Britain's police forces: forever removed from democratic control?', available at: http://www.historyandpolicy.org/papers/ policy-paper-16.html

Williams, G. (1960), 'Questioning by the police: some practical considerations', Criminal Law Review, 325.

Williams, G. (1961), 'England', Journal of Criminal Law \& Criminology, 52: 50 .

Williams, G. (2009), Shafted: The Media, The Miners' Strike and the Aftermath, London: Campaign for Press \& Broadcasting Freedom.

Wilmore, G. (1850), Is Trial By Jury Worth Keeping?, 2nd edn, London

Woofinden, B. (1987), Miscarriages of Justice, London: Coronet Books.

Worrall, A. (1990), Offending Women, London: Routledge.

Wright, R. and M. Miller (2002), 'The screening/bargaining tradeoff', Stanford Law Review, 55: 29.

Young, J. (2011), 'Ours was a thankless task', Law Society Gazette, 3 November.

Young, R. (2008), 'Street policing after PACE: The drift to summary justice', in E. Cape and R. Young (eds), Regulating Policing: The Police and Criminal Evidence Act 1984 Past, Present and Future, Oxford: Hart Publishing. 
Young, R. and D. Wall (1996), 'Criminal Justice, Legal Aid and the Defence of Liberty', in R. Young and D. Wall (eds), Access to Criminal Justice, London: Blackstone Press Ltd.

Zander, M. (1969), 'Unrepresented defendants in the criminal courts', Criminal Law Review, 632.

Zander, M. (1971a), 'Unrepresented defendants in magistrates' courts', New Law Journal, 122: 1042.

Zander, M. (1971b), 'A study of bail/custody decisions in London magistrates' courts', Criminal Law Review, 191.

Zander, M. (1972a), 'Unrepresented defendants in magistrates' courts, 1972', New Law Journal, 1041.

Zander, M. (1972b), 'Access to a solicitor in the police station', Criminal Law Review, 342.

Zander, M. (1974), 'Are too many professional criminals avoiding conviction? A study in Britain's two busiest courts', Modern Law Review, 87: 28.

Zander, M. (1978), 'The right to silence in the police station and the caution', in P. Glazebrook (ed.), Re-shaping the Criminal Law, London: Stevens.

Zander, M. (1991), 'What the annual statistics tell us about pleas and acquittals', Criminal Law Review, 252.

Zander, M. (2001), Lord Justice Auld's Review of the Criminal Courts: A Response, available at: http://www.lse.ac.uk/collections/law/staff $\% 20$ publications $\% 20$ full $\% 20$ text/zander/auld_response_web.pdf

Zander, M. (2009), 'Zander on Woolf', New Law Journal, 13 March.

Zander, M. and P. Henderson (1993), Crown Court Study, Research Study No.19, The Royal Commission on Criminal Justice, London: HMSO.

\section{NEWS AND NEWSPAPER ARTICLES}

Ahmed, K. (2000), 'Molester walks free', The Observer, 22 October.

Airs, T. (2012), 'Judge slams "blunders" in baby assault case', Banbury Cake, 9 April, available at: http://www.banburycake.co.uk/news/9638668. Judge_slams_ blunders in_baby_assault_case/

$B B C$ News (2009), '[W]e accept that the wrong decision was made not to charge Mr Mannan at an earlier stage', 5 March.

$B B C$ News (2010), 'CPS apologises to woman over assault case collapse', 7 October.

$B B C$ News (2011a), 'Private detective axe murder case collapses 24 years on', 11 March.

BBC News (2011b), 'Ratcliffe power station protestors cleared on appeal', 19 July. 
$B B C$ News (2011c), 'Riot sentence "feeding frenzy" claims anger magistrates', 29 August.

$B B C$ News (2011d), 'Police chiefs in misconduct probe over Kevin Nunes murder', 23 December.

$B B C$ News (2012a), 'Nine men cleared of murdering UDA man Tommy English', 22 February.

$B B C$ News (2012b), 'Met race claim victims "made to suffer," says retiring officer', 9 May.

$B B C$ News (2012c), 'Lynette White: fresh concerns raised over investigation', 13 August.

$B B C$ News (2012d), 'Mark Haddock UVF supergrass trial cost taxpayers $£ 11.5 \mathrm{~m}$ ', 11 October.

BBC News (2012e), 'Attorney general “cannot review” GBH sentence', 20 January.

BBC News (2012f), 'Sex offenders in Yorkshire given police cautions', 18 May.

BBC News (2012g), 'Serco chief executive stands down after scandal', 25 October.

$B B C$ News (2012h), 'David Leggatt jailed for rape and sex assaults on girls in Fife', 19 December.

BBC News (2013a), 'Police chief Dal Babu criticizes ethnic recruitment', 4 February.

BBC News (2013b), 'Timeline: Daniel Morgan axe murder', 21 May.

BBC News (2013c), 'Police corruption: criminals "give officers steroids", 23 January.

BBC News (2013d), 'Undercover police "used dead children's identities", 3 February.

BBC News (2013e), 'Colchester General Hospital: police probe cancer treatment', 5 November.

$B B C$ News (2013f), 'Lord Neuberger, UK's most senior judge, voices legal aid fears', 5 March.

BBC News (2013g), 'Cleveland Police deputy chief constable Derek Bonnard sacked', 25 March.

$B B C$ News (2013h), 'Former police officer admits selling stories to Sun', 26 April.

$B B C$ News (2013i), 'Daniel Morgan murder: inquiry to examine "police corruption", 10 May.

$B B C$ News (2013j), 'Sir Norman Bettison smear claim shocks Lawrence witness', 5 July.

$B B C$ News (2013k), 'Angela England jailed over Conwy false rape allegation', 10 August. 
$B B C$ News (20131), 'Benefit fraud could lead to 10-year jail terms, says DPP', 16 September.

BBC News (2013m), 'Courts failing child sex abuse victims, says NSPCC', 5 October.

BBC News (2013n), 'Stuart Lawrence race complaint against Met upheld', 12 October.

BBC News (2013o), 'Rape case referrals to CPS reach five-year low', 27 October.

BBC News (2013p), 'Crime victims to get voice in court under new code', 29 October.

$B B C$ News (2013q), 'Orgreave miners strike handling referred to IPCC', 16 November.

BBC News (2013r), 'G4S £24.1m tagging offer rejected by ministers', 19 November.

BBC News (2013s), 'Police fix crime statistics to meet targets, MPs told', 19 November.

$B B C$ News (2013t), 'Essex policewoman jailed for "rape" lie', 6 December.

BBC News (2014), 'Policing "damaged" after Stephen Lawrence report', 6 March.

Berlins, M. (1971a), 'Rules now helping guilty will soon go', The Times, 8 April.

Berlins, M. (1971b), 'Call to ease police questioning methods', The Times, 17 July.

Bowcott, O. (2013a), 'Legal aid cuts putting huge fraud trial at risk', The Guardian, 15 November.

Bowcott, O. (2013b), 'Criminal barristers announce half-day refusal to work in legal aid protest', The Guardian, 3 December.

Bowcott, O. (2013c), 'Solicitors to join walkout over MoJ plans to cut legal aid fees by up to $30 \%$, The Guardian, 1 December.

Bowcott, O. (2013d), 'Critics of legal aid cuts force Law Society vote', The Guardian, 19 November.

Bowcott, O. (2013e), 'Lawyers to earn higher legal aid fees for early guilty pleas', The Guardian, 1 November.

Bowcott, O. (2014), 'Declining crime rates will "save $£ 80 \mathrm{~m}$ a year in legal aid", The Guardian, 13 January.

Bowcott, O. and S. Bates (2011), 'Riots: magistrates advised to "disregard normal sentencing"', The Guardian, 15 August.

Bowcott, O., P. Walker and L. O'Carroll (2014), 'Courts close across England and Wales as lawyers protest at legal aid cuts', The Guardian, 6 January.

Brown, C. (1993), 'Howard seeks to placate "angry majority": Home 
Secretary tells party that balance in criminal justice system will be tilted towards public', The Independent, 7 October.

Burrell, I. and J. Benetto (1999), 'Police unit to blame for "dozens more injustices", The Independent, 1 November.

Carrell, S. (2014), 'Police stop and search rates in Scotland four times higher than in England', The Guardian, 17 January.

Clarke, K. (2011), 'Punish the feral rioters but address our social deficit too', The Guardian, 5 September.

Conn, D. (2012), 'Hillsborough investigation should be extended to Orgreave, says NUM leader', The Guardian, 21 October.

Davies, C. (1970), 'The innocent who plead guilty', Law Guardian, March, pp. $9-15$.

Dodd, V. (2011), 'Asian people 42 times more likely to be held under terror law', The Guardian, 23 May.

Dodd, V. (2012), 'Police marksman was “absolutely certain” Mark Duggan was holding gun", The Guardian, 26 September.

Dodd, V. (2013a), 'Minorities stopped disproportionally in decade after Macpherson report', The Guardian, 22 April.

Dodd, V. (2013b), 'Former judge to examine role of police corruption in murder investigation', The Guardian, 10 May.

Duffin, C. (2013), 'Woman who made a string of false rape allegations is jailed', The Telegraph, 9 July.

Dworkin, R. (2006), 'It is absurd to calculate human rights according to a cost-benefit analysis', The Guardian, 24 May.

Dyer, C. (2000), 'Making a pact with the devil', The Guardian, 30 October.

Express \& Star (2009), 'Judge hits out over handling of raid case', 8 May.

Foley, C. (2009), 'Police violence and death: an old story', The Guardian, 26 April.

Gibb, F. (2005), 'Courts to reduce time-wasting', The Times, 5 April.

Gilligan, A. (2012), 'Have the men in blue crossed the line?', The Telegraph, 21 December.

Grice, A. and P. Peachey (2012), 'Lawrence murder: police "corruption" will be investigated', The Independent, 10 March.

Halliday, J. (2014), 'Plebgate row: police officer pleads guilty', The Guardian, 10 January.

Halpin, T. (1994), 'Judge outraged by CPS plea-bargain', Daily Mail, 23 June.

Harper, T. (2014a), 'Revealed: how gangs used the Freemasons to corrupt police', The Independent, 13 January.

Harper, T. (2014b), 'The corruption of Britain: UK's key institutions infiltrated by criminals', The Independent, 10 January.

Harper, T. (2014c), 'Scotland Yard's rotten core: police failed to address Met's "endemic corruption", The Independent, 10 January. 
Hexham Courant (2008), 'Judge criticizes knife case charge', 28 July.

Higham, N. (2014), 'Cabinet papers reveal "secret coal pits closure plan", $B B C$ News, 3 January.

Howard, M. (1993), The Daily Telegraph, 7 October.

Hunter, N. (2013), 'Soldier tells how false rape claims ruined his life', The Northern Echo, 24 June.

Jennings, A. and P. Lashmar (1990), 'The wall of silence that refuses to fall', The Guardian, 13 August.

Kamal, A. (2000), 'Move to ban plea bargains after molester walks free', The Observer, 22 October.

Kennedy, H. (2014), 'The David Miranda judgement has chilling implications for press freedom, race relations and basic justice', The Guardian, 19 February.

King, M. (2011), 'Crackdown on tax evasion leads to rise in criminal convictions', The Guardian, 27 August.

Lakhani, N. (2012), 'Night the row about riot sentencing was reignited', The Independent, 16 June.

Law Society Gazette (1970), Comment, March.

Leake, C., M. Delgado and G. Arbuthnott (2010), 'Police have shot dead 33 people since 1995 - only two marksmen have ever been named', Mail Online, 26 September.

Lewis, P. (2010), 'Blair Peach killed by police at 1979 protest, Met report finds', The Guardian, 27 April.

Lissaman, C. (2011), 'Birmingham Six Release Remembered', BBC News, 14 March.

Liverpool Echo (2012), 'Judge blasts CPS for "undercharging" thug who smashed glass over drinker's head in Southport pub', 22 August.

MacPherson, H. (1970), 'Is it backroom British justice?', The Guardian, 24 February.

Mail Online (2010), 'Police killed Blair Peach during riot three decades ago then launched a cover-up', 28 April.

Mail Online (2012), 'Eleven Met firearms officers deny collusion after admitting writing their statements together in the same room after Mark Duggan shooting', 28 September.

Mancunian Matters (2012), 'Rochdale child sex ring: Crown Prosecution Service apologises to teenage sex victim for "not taking her seriously", 9 May.

McLagan, G. (2004), 'The last old-style fit-up?', The Guardian, 2 November. Mullins, A. (2000), 'Elite police squad are jailed for drug deals', The Independent, 5 August.

Narain, J. (2011), "Judge attacks "absurd" deal that saved serial thief from 4 years' jail’, Mail Online, 28 April. 
News \& Star (2011), 'Carlisle judge criticizes CPS over danger driver charge', 9 July.

News \& Star (2012), 'Cumbrian man jailed for brutal attack on his own mum', 5 May.

News of the World (1984), 'Godfather Scargill's mafia mob', 7 October.

Norton-Taylor, R. (2000), 'Pat Pottle', The Guardian, 3 October.

Owers, A. (2014), 'Police co-operation lacking in Mark Duggan probe by IPCC', The Guardian (Letters), 14 January.

Payne, T. (2014), 'Brothel-running, child abuse images, and selling firearms among nearly 200 crimes committed by police in last three years', The Independent, 16 January.

Peachey, P. (2013), 'Collapse of Britain's biggest police corruption trial: "No misconduct involved" in Cardiff Three fit-up case', The Independent, 16 July.

Peirce, G. (2011), 'The Birmingham Six', The Guardian, 12 March.

Porter, H. (2013), 'Police corruption is now so rife that radical reform is the only answer', Observer, 20 October.

Rawstorne, T. (2003), ' $£ 1.7 \mathrm{~m}$ crook walks free after plea-bargain deal', The Daily Mail, 24 April.

Rogers, S. (2012), 'Homelessness jumps by $14 \%$ in a year', The Guardian, 8 March.

Rozenberg, J. (2000), 'Plea bargaining ban angers trial judge', The Telegraph, 21 November.

Rozenberg, J. (2012), 'Chris Grayling, Justice Secretary: non-lawyer and "on the up" politician', The Guardian, 4 September.

Rozenberg, J. (2014), 'Lord Chief Justice helps politicians grasp courts' "hot potato", The Guardian, 4 March.

Ryder, M. (2014), 'Why so many find the Mark Duggan verdict hard to accept', The Observer, 19 January.

Scots Law Times (1980), 15 February.

Shaw, D. (2013a), 'Police chief Dal Babu criticises ethnic recruitment', $B B C$ News, 4 February.

Shaw, D. (2013b), 'Lawrence friend Dwayne Brooks "bugged by police", $B B C$ News, 25 June.

Slater, E. (2012), 'Special report: the return of the supergrass', The Independent, 8 October.

Syal, R. (2013), 'Britain’s £35bn tax gap is "tip of iceberg”, says Margaret Hodge', The Guardian, 28 October.

The Daily Mail (1970a), 'MPs protest at "rigged trials", 23 February.

The Daily Mail (1970b), 'The case of Stephen Carver', 13 April.

The Daily Mail (1970c), 'The case of Ronald Price', 13 April.

The Daily Mail (1970d), 'Are innocent persuaded to plead guilty?', 13 April. 
The Daily Mail (1970e), 'Lawyers to probe plead-guilty court deals', 14 April.

The Daily Telegraph (1970), 'When a judge makes a deal with a barrister', 2 April.

The Daily Telegraph (2010), 'Criminals escape justice due to CPS flaws, says judge', 10 March.

The Guardian (1969), "'Plea bargains" on the way?', 14 October.

The Guardian (2000), 'DPP inquiry into collapse of drugs case', 5 November.

The Guardian (2010), 'DPP apologises to woman failed by courts after sexual assault', 20 September.

The Guardian (2012), 'Police forces confess 944 officers have a criminal record', 2 January.

The Guardian (2013a), 'Welfare fraud and error: how much is the UK losing?', 13 May.

The Guardian (2013b), 'MoJ's misleading evidence on the cost of the legal system', 3 October.

The Guardian (2013c), 'Barristers threaten strike action over cuts to legal aid', 16 November.

The Guardian (2013d), 'PlebGate: police, camera, action', 27 November.

The Independent (2000), 'Elite police squad are jailed for drug deals', 5 August.

The Independent (2013), 'Five police forces investigated over alleged Stephen Lawrence smear campaign', 6 July.

The London Gazette (1990), 'State intelligence', 22 February.

The Observer (2012), 'Justice must be seen to be done in South Wales police scandal', 28 January.

The Sun (1984), 'Scargill's real aim is war', 5 April.

This is Cornwall (2009), 'Judge blasts CPS over savage gang attack case', 24 July.

Tomlinson, S. (2013), 'Britain's newest "underworld king” unmasked after he loses libel claim against Sunday newspaper that labelled him violent and dangerous', Mail Online, 5 July.

Townsend, M. (2012), 'Criminal records of striking miners "should be erased", The Observer, 1 December.

Tyler, R. (1970), 'Lord Parker bans court deals', The Daily Mail, 25 April.

Wales Online (2011), 'Judge attacks CPS over sentence for wife beater', 13 June.

Wales Online (2012), 'CPS issues apology after collapse of assault trial', 12 April.

Walker, P. and V. Dodd (2012), 'Cleveland police chief sacked for "shameful" misconduct', The Guardian, 5 October. 
Western Telegraph (2010), 'Judge slams Haverford magistrates for "shambolic" case', 26 May.

White, C. (1973), 'I pleaded guilty after court "deal”', The Daily Mail, 13 August.

Young, H. (1992), 'In tune with the times', Guardian Weekly, 2 August.

\section{TELEVISION PROGRAMMES}

BBC Television, Braden's Week, 21 February 1970.

BBC Television, Police (Producer: Roger Graef), 1982.

BBC Television, Police: Operation Carter: A Different World (Producer: Roger Graef), 1982.

\section{WEBSITES}

CRISIS website, available at: http://www.crisis.org.uk/

'Insurance Fraud Bureau and City of London case collapses', 5 December, 2011, available at: http://www.cisionwire.com/rms/r/insurance-fraudbureau-and-city-of-london-case-collapses,c9196130

'Prosecutors criticized for not levelling a more serious charge in racism case', 24 March, 2011, available at: http://www.foreignersinuk.co.uk/ news-sos_racism-prosecutors_criticized_for_not_levelling_a_more_seri ous_charge_in_racism_case_2738.html

Tooks Chambers website, available at: http://www.tooks.co.uk/ 